\section{Canadian budget boost for science}

Montreal

Paul Martin, Canada's Finance Minister, this week unveiled a budget that will cut taxes for both individuals and corporations by Can $\$ 58$ billion (US $\$ 39.6$ billion) over the next five years. The move - intended to stem the 'brain drain' to the United States - will be accompanied by a rise in spending on research and innovation to more than Can\$4.1 billion next year.

Two scientific organizations are created in the budget. Genome Canada has Can\$160 million to fund five genome science centres. These will provide laboratory services and technology to researchers from government, universities and the private sector.

The Canadian Foundation for Climate and Atmospheric Sciences will provide Can $\$ 60$ million in block grants over six years to climate-science institutes and universities, as well as peer-reviewed research grants.

In addition, Can $\$ 900$ million over five years goes to the Canada Foundation for Innovation, which provides infrastructure grants, bringing the government's total investment to Can $\$ 1.9$ billion. A Can $\$ 900$ million contribution over five years will establish 2,000 university research chairs (see Nature 401, 731; 1999).

Other initiatives include Can $\$ 210$ million over three years for the Climate Change Action Fund, established in 1998 to help Canada meet its international commitments, and for other energyefficiency and renewable-energy schemes.

The Canadian International Development Agency will get Can\$100 million over four years to help developing countries reduce greenhouse gases and promote sustainable development. And Can\$90 million will be spent over three years to create a national strategy on endangered species, including legislation (see Nature 401, 418; 1999).

Martin's tax-reduction plans are funded from a Can $\$ 6$ billion surplus. But some argue that the extra science and technology funding lacks a clear focus. "There's no big strategy," says John de la Motte, a science-policy analyst at the University of Ottawa. "It's putting money back to where it was taken from" by recent spending cuts. David Spurgeon

\title{
Robert May to head Royal Society
}

\section{London}

Sir Robert May, currently chief scientific adviser to the British government and head of the Office of Science and Technology, is to be the new president of the Royal Society. He was elected this week to succeed the current president, Sir Aaron Klug, when the latter's term of office expires at the end of November.

May, a physicist by training who has since become a world-renowned mathematical biologist, is professor of zoology at the University of Oxford, and was appointed to his government post in 1995 (see Nature 375, 527; 1995).

He has played a key role in reforming the government's science advisory procedures in the wake of the bovine spongiform encephalopathy crisis. May's five-year contract expires at the end of August.

\section{Post-Cold War needs 'new forms of scientific linkage'}

Paris

New international links between scientists are needed to meet the political realities of the post-Cold War world, a meeting in Paris was told last weekend.

Speakers at the meeting, held on the changing political role of scientific collaboration, emphasized the need to create and strengthen scientific networks in areas such as the former Yugoslavia or North Africa, where political tensions are high. They suggested that countries with experience of creating such networks should help.

Participants included seasoned experts in science and public policy, among them Alexander King, former director-general for scientific affairs for the Organization for Economic Cooperation and Development (OECD), and William Nierenberg, former deputy secretary-general for science at the North Atlantic Treaty Organization (NATO) and subsequently director of the Scripps Institution of Oceanography in California.

The conference was organized by Futuribles International, a non-profit think-tank based in Paris, and the George C. Marshall Institute. Scientists from North Africa, Eastern Europe and the Middle East were also present.

Several speakers described the influential role of scientists on the international scene during the period between the end of the Second World War and the start of the Cold War. But much attention was given to how significantly the interaction between science and world politics has changed in the postCold War period.

One change has been the geographical shift in focus from East-West conflicts to other political hot spots, such as the Middle East, Southeast Asia, the former Yugoslavia and the North-South development gap.

It was pointed out, for example, that although many of the organizations created to ease East-West tensions after the Second

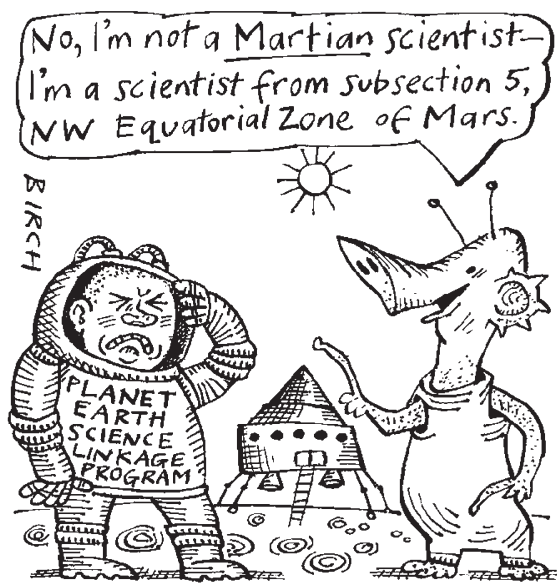

World War - such as NATO, the OECD and the United Nations Educational, Scientific and Cultural Organization (Unesco) - have thriving scientific programmes, networks need to be formed among scientists to address current political realities.

"What is least likely is that we'll have a repeat of the Cold War and that the institutions that came out of it will be able to take care of today's problems," said Jesse Ausubel, director of the programme for the human environment at the Rockefeller University, New York.

Several speakers commented that there is substantial scientific networking within Europe. But this remains rare in politically troubled regions.

Abdelhamid Chorfa, an economist, statistician and demographer from the Institut de Stratégie in Algiers, pointed out that the post-colonial scientific infrastructure of North Africa still lacks international networks, largely owing to political conflicts.

"Scientists still define themselves by the nation from which they come," said Eugene Skolnikoff, professor emeritus of political science at the Massachusetts Institute of Technology.
Heather McCabe 